\title{
Analisis Location Quotient (LQ) Tanaman Cabai Besar (Capsicum annuum L.) di Provinsi Sumatera Utara
}

\section{Location Quotient (LQ) Analysis of Large Chili Plant (Capsicum annuum L.) in North Sumatera}

\author{
Brama Caridio Subambhi*, Siti Mardiana \& Faoeza Hafiz Saragih \\ Program Studi Agribisnis, Fakultas Pertanian, Universitas Medan Area, Indonesia
}

\begin{abstract}
Abstrak
Provinsi Sumatera Utara merupakan Provinsi yang memiliki sektor potensial hortikultura yaitu tanaman cabai besar menjadi program pengembangan jangka panjang tahun 2016-2045 yang disampaikan pada Musyawarah Perencanaan Pembangunan Pertanian (Musrenbangtan). Komoditas prioritas yang menjadi fokus utama pengembangan hortikultura adalah komoditas cabai, bawang merah dan bawang putih. Hal ini dapat dilihat pada data Badan pusat Statistik (BPS) Provinsi Sumatera Utara. Tujuan penelitian ini yaitu, untuk mengetahui di Kabupaten mana yang menjadi basis tanaman cabai besar di Provinsi Sumatera Utara. Metode analisis yang digunakan yaitu, Analisis Location Quotient (LQ) dengan data digunakan dalam penelitian iniadalah data sekunder. Luas tanam tanaman cabai besar dan produksi tanaman cabai besar selama kurun waktu sepuluh tahun terakhir dari 2007 sampai dengan 2016. Hasil Analisis Location Quotient (LQ) menunjukan sektor basis luas tanam cabai besar terdapat 5 Kabupaten tertinggi yaitu, Kabupaten Batu-Bara, Kabupaten Phak-paak Bharat, Kabupaten Dairi, Kabupaten Humbang Hasundutan, Kabupaten Padang Lawas Utara. Sektor basis produksi cabai besar terdapat 5 Kabupaten tertinggi yaitu. Kabupaten Phak-pak Bharat, Kabupaten Batu bara, Kabupaten Mandailing Natal, Kabupaten Langkat dan Kabupaten Nias.
\end{abstract}

Kata Kunci: Cabai Besar, Location Quotient (LQ), Sektor Basis.

\begin{abstract}
North Sumatra Province is a province that has a potential horticulture sector, which is a large chili plant, which is a long-term development program for 2016-2045, which was delivered at the Agricultural Development Planning Consultation (Musrenbangtan). Commodities priority becomes the main focus is the development of horticultural commodities chili, onion and garlic. This can be seen in the data from the Central Statistics Agency (BPS) of North Sumatra Province. The purpose of this study is to find out which regency is the base for large chili plants in North Sumatra Province. The analytical method used is, Location Quotient (LQ) Analysis with the data used in this study is secondary data. The planting area of large chilli plants and the production of large chili plants during the last ten years from 2007 to 2016. The results of the Location Quotient (LQ) Analysis show that the sector of the base for large chilli planting area has 5 highest districts, namely, Batu-Bara Regency, Phak-paak Bharat Regency, Dairi Regency, Humbang Hasundutan Regency, North Padang Lawas Regency. there are 5 highest chilli production base sectors, namely. District of Phak-pak Bharat, Batu Bara Regency, Mandailing Natal District, Langkat Regency and Nias Regency.

Keywords: Chili, Location Quotient (LQ), Basis Sectors.
\end{abstract}

How to Cite: Brama, C.S. Siti, M. \& Faoeza, H.S. (2020). Analisis Location Quotient (LQ) Tanaman Cabai Besar di Provinsi Sumatera Utara. Jurnal Ilmiah Pertanian (JIPERTA), 2(2): 169-179.

*E-mail: bramacaridio@gmail.com ISSN 2550-1305 (Online)

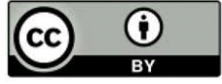




\section{PENDAHULUAN}

Sektor pertanian merupakan salah satu sektor andalan dalam pembangunan perekonomian nasional. Peranannya sebagai menyumbang pembentukan Produk Domestik Bruto penyediaan sumber devisa melalui ekspor, penyediaan pangan dan bahan baku industri, pengatasan kemiskinan, penyediaan lapangan kerja dan perbaikan pendapatan masyarakat. Sektor pertanian di Indonesia terdiri dari beberapa sub sektor, yaitu sub sektor tanaman pangan, hortikultura, peternakan dan perkebunan. Sub sektor hortikultura merupakan komoditas yang cukup potensial dikembangkan secara agribisnis, karena punya nilai ekonomis dan nilai tambah cukup tinggi dibandingkan dengan komoditas lainnya. Selain fungsi ekonomi tersebut tanaman hortikultura mempunyai nilai kalori cukup tinggi, merupakan sumber vitamin, mineral, serat alami dan anti-oksidan, sehingga selalu diperlukan oleh tubuh sebagai sumber pangan maupun nutrisi serta berpengaruh terhadap pendapatan dan kesejateraan petani. Melihat manfaat dan fungsinya dapat dikatakan hortikultura dapat diandalkan untuk memajukan perekonomian Indonesia (Hutauruk, 2018; Ilyasa, et al., 2018; Sihotang, et al., 2019; Syahputra, et al, 2017).

Hortikultura memegang peran penting dan strategis karena perannya sebagai komponen utama pada pola pangan harapan. Komoditas hortikultura khususnya sayuran dan buah-buahan memegang bagian terpenting dari keseimbangan pangan, sehingga harus tersedia setiap saat dalam jumlah yang cukup, mutu yang baik, aman konsumsi, harga yang terjangkau, serta dapat diakses oleh seluruh lapisan masyarakat. Jumlah penduduk Indonesia yang besar sebagai konsumen produk hortikultura yang dihasilkan petani merupakan pasar yang sangat potensial, dari tahun ke tahun menunjukkan kecenderungan semakin meningkat dalam jumlah dan persyaratan mutu yang diinginkan (Adetiya, 2017; Babara, et al., 2017; Eliyatiningsih, \& Mayasari, 2019).

Pada tahun 2018, Direktorat Jenderal Hortikultura memiliki program dan kegiatan hortikultura yang disampaikan pada Musyawarah Perencanaan Pembangunan Pertanian (Musrenbangtan) Nasional 2018 untuk melaksanakan program pengembangan jangka panjang hortikultura dari tahun 2016-2045 untuk peningkatan produksi dan nilai tambah produk hortikultura. Pelaksanaan program ini merupakan lanjutan dari program Direktorat Jenderal Hortikultura tahun 2016 yaitu upaya mewujudkan kedaulatan pangan dan agroindustri yang menjadi bagian dari agenda NAWACITA. Komoditas prioritas yang menjadi fokus utama pengembangan hortikultura adalah komoditas cabai, bawang merah serta bawang putih. Oleh karena itu, Direktorat Jenderal Hortikultura telah menetapkan langkah perencanaan jangka panjang untuk pembangunan cabai, bawang merah, bawang putih dengan disusunnya peta jalan pengembangan cabai, bawang merah, serta bawang putih tahun 2016 - 2045 (Musrenbangtan, 2017).

Dengan demikian, dalam rangka melanjutkan program dan kebijakan yang sudah ada serta meningkatkan kinerja pembangunan hortikultura maka Direktorat Jenderal Hortikultura melakukan penekanan yang signifikan pada peningkatan produksi melalui budidaya hortikultura sebagai upaya mempersiapkan produk hortikultura Indonesia yang bermutu, aman konsumsi dan berdaya saing di pasar domestik dan internasional 
(Lakin Horti, 2016) Oleh karena itu perlu kajian yang lebih mendalam mengenai kabupaten/kota yang mempunyai sektor basis komoditas cabai besar untuk dikembangkan di provinsi Sumatera Utara. Oleh sebab itu penelitian ini mengambil judul: Analisis Location Quotient (LQ) Tanaman Cabai Besar Di Provinsi Sumatera Utara.

Berdasarkan latar belakang maka permasalahan yang dalam artikel ini adalah kabupaten/kota mana yang merupakan basis tanaman cabai besar di Provinsi Sumatera Utara. Adapun tujuan penelitian ini sesuai dengan rumusan permasalahan di atas maka tujuan penelitian ini adalah untuk mengetahui kabupaten/kota di Provinsi Sumatera Utara yang memiliki basis tanaman cabai besar.

\section{METODE PENELITIAN}

Penelitian ini dilakukan di Provinsi Sumatera Utara dengan pertimbangan Provinsi Sumatera Utara dapat menjadi salah satu sentra tanaman cabai besar di Indonesia yang potensial di luar pulau Jawa. Penentuan lokasi penelitian ini ditentukan secara purposive atau dengan sengaja, dengan pertimbangan bahwa Provinsi Sumatera Utara wilayah yang sangat potensial untuk di kembangkan. Waktu penelitian dilakukan pada bulan Mei 2018.

Data yang dikumpulkan dalam penelitian ini adalah data sekunder. Data sekunder tersebut diperoleh dari instansi pemerintah yang terkait seperti Dinas Tanaman Pangan dan Hortikultura Provinsi Sumatera Utara, Badan Pusat Statistik Provinsi Sumatera Utara dan Intansi-intansi lain yang terkait. Data yang digunakan dalam penelitian ini data time series luas tanam dan produksi kabupaten/kota di Provinsi Sumatera Utara sepanjang 10 tahun dari tahun 2007-2016.

Metode yang digunakan dalam penelitian ini adalah metode penelitian deskritip analisis, yaitu suatu metode yang bertujuan mendeskripsikan atau memberikan gambaran terhadap suatu obyek penelitian yang diteliti melalui sempel atau data yang telah di terkumpul dan membuat kesimpulan yang berlaku umum. Penelitian ini menggunakan metode deskriptif dan metode kuantitatif. Pemakaian metode deskriptif untuk melihat perkembangan luas tanam dan produksi cabai besar di kabupaten/kota yang ada di provinsi Sumatera Utara. Penggunaan metode kuantitatif digunakan untuk menghitung hal yang berkaitan dengan penelitian. Adapun alat analisis yang digunakan untuk menjawab tujuan penelitian yaitu dengan menggunakan analisis Location Quotient (LQ).

Menurut Azhar (2014) Analisis LQ merupakan cara untuk mengukur kemampuan suatu daerah dalam sektor kegiatan tertentu yang tidak memberikan suatu kesimpulan akhir tetapi sudah memberi gambaran akan kemampuan daerah pada sektor tertentu. Dengan analisis LQ dapat diketahui sektor pertanian apa saja yang dominan untuk dikembangkan. Menurut Agustina R, (2014) Analisis LQ digunakan untuk mengkaji kondisi perekonomian, mengarah pada identifikasi spesialisasi/basis kegiatan perekonomian. Sehingga nilai LQ yang sering digunakan untuk penentuan sektor basis dapat dikatakan sebagai sektor yang akan mendorong tumbuhnya atau berkembangnya sektor lain serta berdampak pada penciptaan lapangan kerja. 


\section{Analisis Location Quotient (LQ)}

Besarnya nilai LQ menurut Hendayana. R (2003) di peroleh persamaaan berikut:

$$
\boldsymbol{L} \boldsymbol{Q}=\frac{{ }_{\boldsymbol{P i} / \boldsymbol{P t}}}{\boldsymbol{P} \boldsymbol{i} / \boldsymbol{P t}}
$$

Keterangan : L : Indeks Location Quotient tanaman cabai besar di Kabupaten j Propinsi Sumatera Utara, pi : Nilai luas tanam/produksi tanaman cabai besar pada tingkat kabupaten di provinsi Sumatera Utara (Ha), pt : Nilai total luas tanam/produksi komoditas hortikultura tanaman sayur-sayuran pada tingkat kabupaten di provinsi Sumatera Utara (Ha), Pi : Nilai luas tanam/produksi tanaman cabai besar pada tingkat provinsi Sumatera Utara (Ha), Pt : Nilai total luas tanam/produksi komoditas hortikultura tanaman sayur-sayuran pada tingkat provinsi Sumatera Utara (Ha). Kriteria: a. Jika nilai LQ $>1$ berarti tanaman cabai besar tersebut termasuk dalam komoditi unggulan atau sektor tersebut tergolong basis, b. Jika nilai $L Q<1$ berarti tanaman cabai besar tersebut termasuk dalam komoditas bukan unggulan atau sektor tersebut non basis.

\section{HASIL DAN PEMBAHASAN}

\section{Analisis Location quotient (LQ) Komoditas Tanaman Cabai besar Di Provinsi Sumatera Utara}

Kondisi alam sebagian besar daerah Sumatera Utara yang subur merupakan salah satu dasar potensial bagi usaha pertanian, karena berbagai komoditas tanaman dapat tumbuh dengan subur. Salah satu komoditas pertanian yang tumbuh subur di Sumatera Utara komoditas tanaman cabai besar. Karena merupakan komoditas yang banyak digunakan, cabai besar memiliki nilai ekonomis yang tinggi dan banyak diusahakan oleh petani di Sumatera Utara. Selain itu, tanaman ini merupakan tanaman yang mudah ditanam di dataran rendah ataupun di dataran tinggi, sehingga dapat ditemukan di seluruh Kabupaten/Kota di Sumatera Utara kecuali Kota Sibolga. Karena dari data Dinas Tanaman pangan dan Hortikultura Sumatera Utara dan Badan Pusat Statistik Sumatera Utara untuk subsektor hortikultura tanaman sayur-sayuran luas tanam dan produksi paling terendah di antara kabupaten/kota lainnya. Untuk tanaman cabai besar sendiri untuk datanya tidak ada dari tahun 2007-2016. Karena selama ini Kota Sibolga memiliki potensi pertanian yang besar hanya subsektor perikanan.

Analisis Location Quotient (LQ) digunakan untuk mengetahui apakah suatu komoditas cabai besar di kabupaten/kota yanag ada provinsi Sumatera Utara dapat digolongkan ke dalam sektor basis atau non basis. Wilayah yang dikatakan sektor basis yang memiliki nilai LQ > 1 merupakan wilayah luas tanam dan produksi komoditas tersebut dan wilayah yang dikatakan non basis yang memiliki nilai $\mathrm{LQ}<1$ merupakan wilayah luas tanam dan produksi komoditas tersebut. Melihat sektor basis dan non basis tanaman cabai besar menjadi salah satu cara pemerintah untuk mengetahui Kabupaten/Kota yang ada di Provinsi Sumatera Utara yang memiliki sektor basis tanaman cabai besar dan pemerintah dapat menentukan kebijakan pengembangan tanaman cabai besar di kabupaten/kota yang ada di Provinsi Sumatera Utara. 
1. Analisis Location Quotient (LQ) Luas Tanam Komoditas tanaman Cabai Besar Di Provinsi Sumatera Utara Tahun 2007-2016

Berikut hasil rata-rata sektor basis luas tanam komoditas tanaman cabai besar dari tahun 2007-2016 berdasarkan 25 kabupaten 8 kota di Provinsi Sumatera Utara menggunakan Analisis Location Quotient (LQ). Terdapat 11 Kabupaten yang memiliki sektor basis luas tamam tanaman cabai besar yaitu Kabupaten Mandailing Natal, Kabupaten Tapanuli Selatan, Kabupaten Tapanuli Utara, Kabupaten Dairi, Kabupaten Langkat, Kabupaten Humb. Hasundutan, Kabupaten Phak-phak Bharat, Kabupaten BatuBara, Kabupaten Padang Lawas Utara, Kabupaten Labuhan Batu Utara, Kabupaten Nias Utara. Dapat di lihat pada gambar grafik dibawah terdapat 11 kabupaten yang memiliki sektor basis luas tanam tanaman cabai besar sebagai berikut :

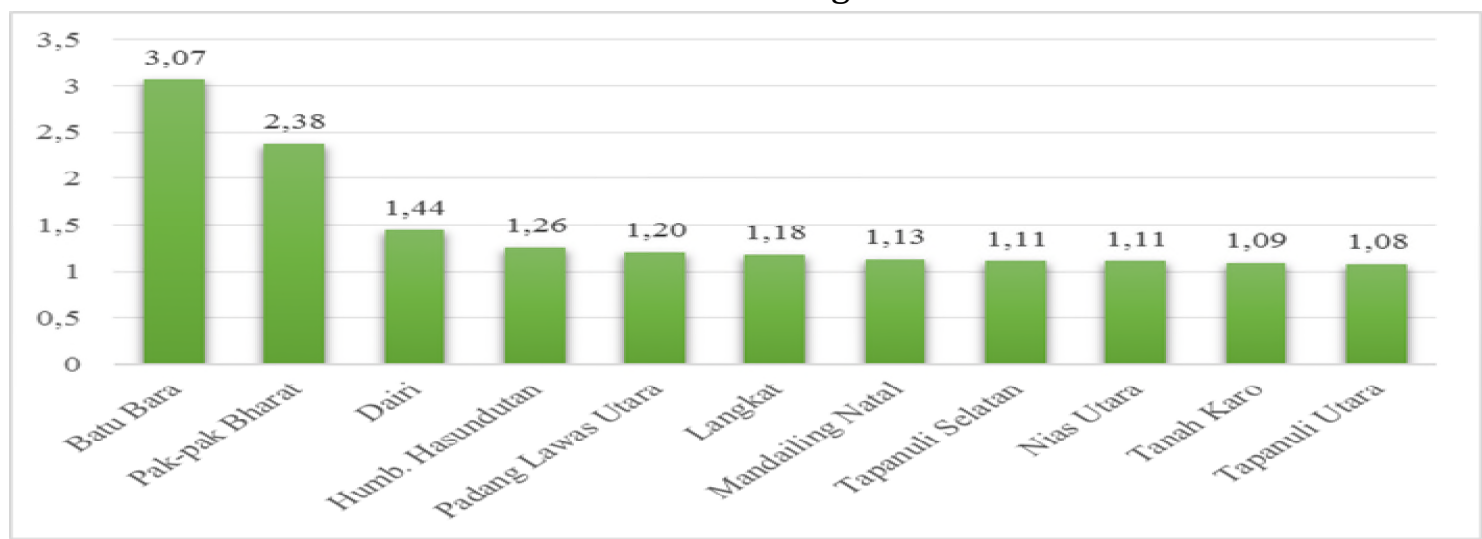

Sumber: BPS Sumut Di Olah Peneliti

Gambar 1. Nilai Location Quotien (LQ) Sektor Basis Luas Tanam Komoditas Tanaman Cabai Besar Di Provinsi Sumatera Utara Tahun 2007-2016

Berdasarkan gambar grafik di atas hasil Location Quotient (LQ) sektor basis luas tanam cabai besar terdapat 5 kabupaten tertinggi yaitu, Kabupaten Batu-Bara sebesar 3,07, Kabupaten Phak-paak Bharat sebesar 2,38, Kabupaten Dairi sebesar 1,44, Kabupaten Humb. Hasundutan sebesar 1,26, Kabupaten Padang Lawas Utara sebesar 1,20. Hal ini menunjukan bahwa ke lima Kabupaten tersebut layak untuk menjadi pengembangan tanaman cabai besar.

Berikut hasil rata-rata sektor non basis luas tanam komoditas tanaman cabai besar dari tahun 2007-2016 berdasarkan 25 kabupaten 8 kota di provinsi Sumatera Utara menggunakan Analisis Loction Quotient (LQ). Terdapat 21 Kabupaten/Kota yang memiliki sektor non basis luas tamam tanaman cabai besar yaitu, Kabupaten Nias, Kabupaten Tapanuli Tengah, Kabupaten Toba Samosir, Kabupaten Labuhan Batu, Kabupaten Asahan, Kabupaten Simalungun, Kabupaten Deli Serdang, Kabupaten Nias Selatan, Kabupaten Samosir, Kabupaten Serdang Bedagai, Kabupaten Padang Lawas, Kabupaten Labuhan Batu Selatan, Kabupaten Labuhan Batu Utara, Kota Tanjung Balai, Kota Pematang Siantar, Kota Tebing Tinggi, Kota Medan, Kota Binjai, Kota Padang Sidempuan, Kota Gunung Sitoli. Dapat di lihat pada gambar grafik dibawah terdapat 10 Kabupaten/Kota yang memiliki sektor non basis luas tanam tanaman cabai besar terendah sebagai berikut : 
Brama Caridio Subambhi, Siti Mardiana \& Faoeza Hafiz Saragih, Analisis Location Quotient (LQ)

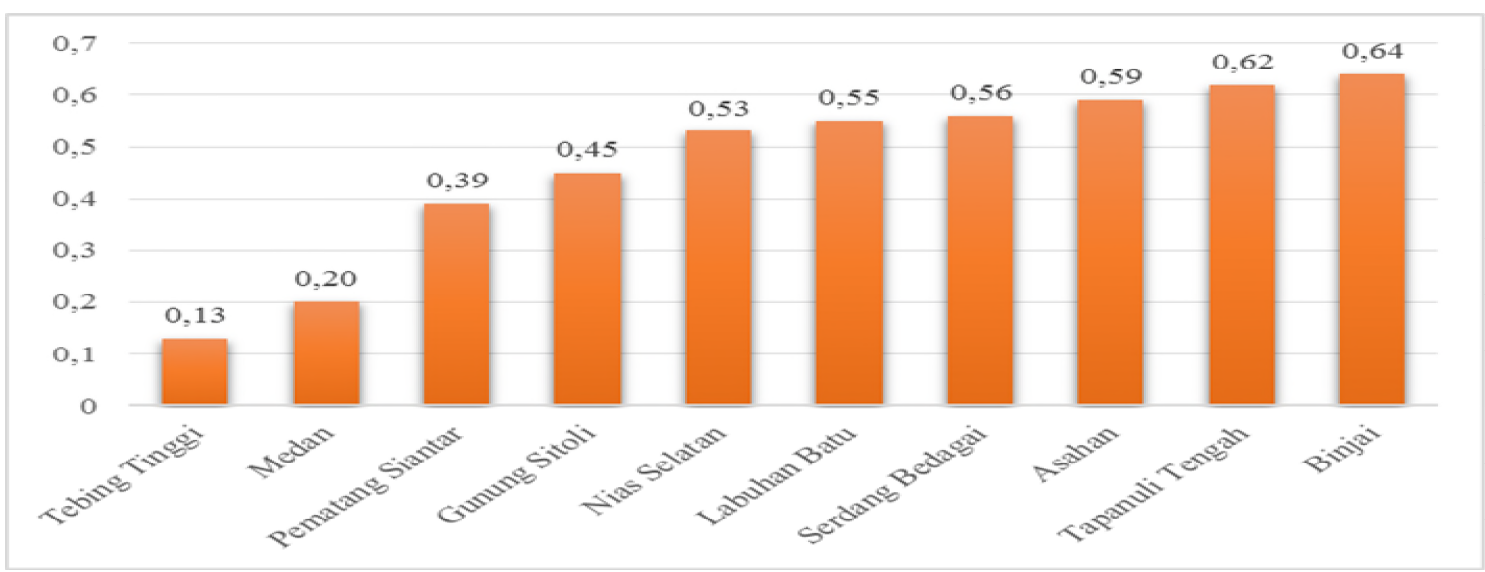

Sumber: BPS Sumut Di Olah Peneliti

Gambar 2. Nilai Location Quotient (LQ) Sektor Non Basis Luas Tanam Komoditas Tanaman Cabai Besar Di Provinsi Sumatera Utara Tahun 2007-2016

Berdasarkan gambar grafik di atas hasil Location Quotient (LQ) sektor non basis luas tanam cabai besar terdapat 5 Kabupaten terendah yaitu, Kabupaten Tebing Tinggi sebesar 0,13, Kota Medan sebesar 0,20, Kota Pematang Siantar sebesar 0,39, Kota Gunung Sitoli sebesar 0,45 dan Kabupaten Nias Selatan sebesar 0,53 hal ini menunjukan ke lima Kabupaten tersebut harus di kembangkan agar dapat memenuhi kebutuhan kabupaten itu sendiri jika kebutuhan kabupaten sudah tercukupi kabupaten tersebut dapat memenuhi kebubutuhan daerah lain.

2. Analisis Location Quotient (LQ) Produksi Komoditas Tanaman Cabai Besar Di Provinsi Sumatera Utara Tahun 2007-2016

Berikut hasil rata-rata analisis Produksi komoditas tanaman cabai besar dari tahun 2007-2016 berdasarkan 25 Kabupaten 8 Kota di Provinsi Sumatera Utara menggunakan Analisis Loction Quotient (LQ). Terdapat 13 kabupaten yang memiliki sektor basis produksi tanaman cabai besar yaitu, Kabupaten Nias, Kabupaten Mandailing Natal, Kabupaten Tapanuli Selatan, Kabupaten Tapanuli Utara, Kabupaten Toba Samosir, Kabupaten Labuhan Batu, Kabupaten Dairi, Kabupaten Deli Serdang, Kabupaten Langkat, Kabupaten Humb. Hasundutan, Kabupaten Phak-phak Bharat, Kabupaten Batu Bara, Kabupaten Padang Lawas Utara. Dapat di lihat pada gambar grafik dibawah terdapat 13 Kabupaten/Kota yang memiliki sektor basis produksi tanaman cabai besar sebagai berikut:

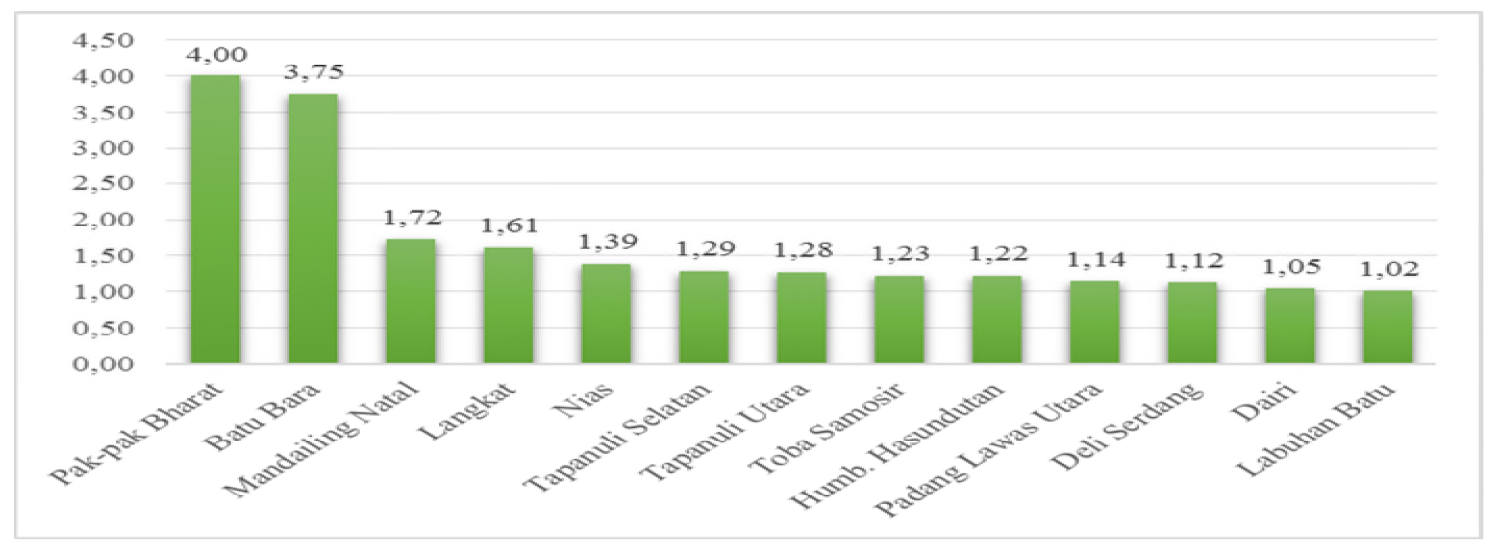




\section{Sumber : BPS Sumut Di Olah Peneliti \\ Gambar 3. Nilai Location Quotien (LQ) Sektor Basis Produksi Komoditas Tanaman Cabai Besar Di \\ Provinsi Sumatera Utara Tahun 2007-2016}

Berdasarkan gambar grafik di atas hasil Location Quotient (LQ) sektor basis produksi cabai besar terdapat 5 kabupaten tertinggi yaitu. Kabupaten Phak-pak Bharat sebesar 4,00, Kabupaten Batu bara 3,75, Kabupaten Mandailing Natal 1,72 Ton, Kabupaten Langkat 1,61 dan Kabupaten Nias 1,39. Hal ini dapat di lihat dari ke lima Kabupaten yang memiliki sektor basis tertinggi layak menjadi pengembangan tanaman cabai besar namun pemerintah daerah harus melihat kabupaten yang memiliki sektor basis.

Berikut hasil rata-rata sektor non basis produksi komoditas tanaman cabai besar dari tahun 2007-2016 berdasarkan 25 kabupaten 8 kota di Provinsi Sumatera Utara menggunakan Analisis Loction Quotient (LQ). Terdapat 19 Kabupaten/Kota yang memiliki sektor non basis produksi tanaman cabai besar yaitu, Kabupaten Tapanuli Tengah, Kabupaten Asahan, Kabupaten Simalungun, Kabupaten Tanah Karo, Kabupaten Nias Selatan, Kabupaten Samosir, Kabupaten Serdang Bedagai, Kabupaten Padang Lawas, Kabupaten Labuhan Batu Selatan, Kabupaten Labuhan Batu Selatan, Kabupaten Nias Utara, Kabupaten Nias Barat, Kota tanjung Balai, Kota Pematang Siantar, Kota Tebing Tinggi, Kota Medan Kota Binjai, Kota Padang Sidempuan, Kota Gunung Sitoli. Dapat di lihat pada gambar grafik dibawah terdapat 10 kabupaten/kota yang memiliki sektor non basis produksi tanaman cabai besar terendah sebagai berikut :

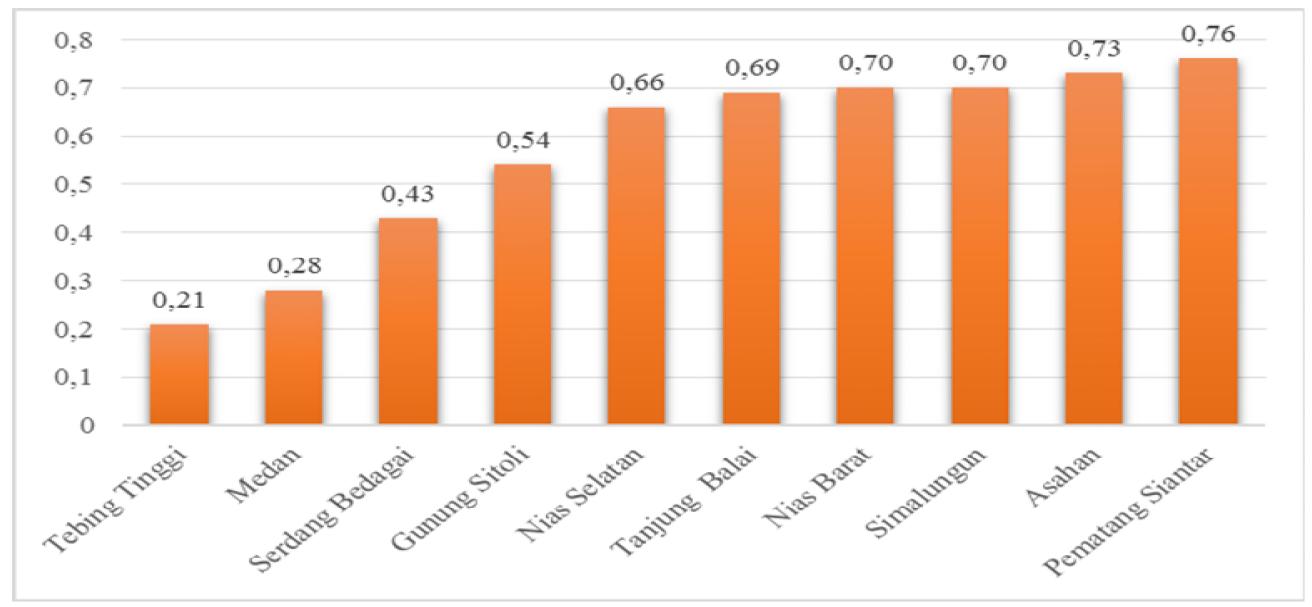

Sumber: BPS Sumut Di Olah Peneliti

Gambar 4. Nilai Location Quotient (LQ) Sektor Non Basis Produksi Komoditas Tanaman Cabai Besar Di Provinsi Sumatera Utara 2007-2016

Berdasarkan gambar grafik di atas hasil Location Quotient (LQ) sektor non basis produksi cabai besar terdapat 5 kabupaten terendah yaitu, Kabupaten Tebing Tinggi sebesar 0,21 Ton, Kota Medan sebesar 0,28 Ton, Kabupaten Serdang Bedagai sebesar 0,43 Ton, Kota Gunung Sitoli sebesar 0,54 Ton dan Kabupaten Nias Selatan sebesar 0,66 Ton. Hal ini dapat dilihat dari ke lima kabupaten yang memiliki sektor non basis terendah harus di tingkatkan lagi produksinya. 


\section{Pembahasan Analisis Location Quotien (LQ) Tanaman cabai Besar Di Provinsi Sumatera Utara Thaun 2007-2016}

Berdasarkan gambar grafik luas tanam dan produksi Kabupaten yang memiliki sektor basis luas tanam tetapi tidak memiliki sektor basis produksi dan sebaliknya kabupaten yang tidak memiliki sektor basis luas tanam tetapi memiliki sektor basis produksi cabai besar di Provinsi Sumatera Utara.

Adapun kabupaten yang memiliki sektor basis luas tanam rata-rata tetapi tidak memiliki sektor basis produksi yaitu, Kabupaten Tanah Karo dan Nias Utara namun kedua kabupaten tersebut memiliki rata-rata sektor basis luas tanam tertinggi. Hal ini terjadi karena kurangnya produksi Kabupaten Tanah Karo terjadi karena kondisi alam yang kurang mendukung pertumbuhan tanaman cabai besar dan tanaman menjadi kurang baik dalam memproduksi menyebabkan gagal panen yang dialami petani, namun jika di lihat dari data produksi tanaman cabai besar dari tahun 2007-2016 Kabupaten Tanah Karo paling tertinggi. Tetapi pengaruh nilai pembagi dapat mempengaruhi hasil sektor basis/non basis kabupaten/kota pengaruh nilai pembagi yaitu, pt (nilai total produksi komoditas hortikultura tanaman sayur-sayuran pada tingkat kabupaten di Provinsi Sumatera Utara) sangat berpengaruh karena semakin rendah nilai total produksi komoditas hortikultura pada tingkat kabupaten/kota maka semakin besar nilai sektor basis kabupaten/kota sebaliknya jika semakin besar nilai total produksi komoditas hortikultura pada tingkat kabupaten/kota maka semakin rendah atau sektor non basis kabuapten/kota yang ada Provinsi Sumatera Utara. Begitu juga Kabupaten Nias Utara walaupun memiliki sektor basis luas tanam cabai besar namun produksi tanaman cabainya tidak maksimal menyebabkan produksi tanaman cabai besar menjadi non basis.

Oleh karena itu pemerintah dalam menentukan kebijakan pengembangan harus lebih teliti lagi dengan melihat kondisi alam yang dimiliki kabupaten/kota memiliki potensi untuk ditanamin atau tidak dan peran pemerintah sangat di butuhkan untuk memberikan bantuan tidak hanya perluasan tanam cabai besar dan penyuluhan secara langsung kepada Petani cabai besar, bantuan berupa bibit, pupuk, insektisida, mulsa, dan pelatihan-pelatihan kepada para petani cabai besar, serta memberikan alat yang di butuhkan oleh para petani sehingga petani mampu memamfaatkan luas tanam yang memiliki sektor basis untuk menigkatkan produksi cabai besar. Dengan demikian kabupaten tersebut menjadi kabupaten sektor basis produksi dapat membuat perkembangan produksi daerah meningkat di tahun 2017 dan 2018.

Sedangkan untuk kabupaten yang tidak memiliki sektor basis luas tanam tetapi memiliki sektor basis produksi yaitu, Kabupaten Nias, Kabuapten Toba Samosir, Kabupaten Labuhan Batu, Kabupaten Deli Serdang yang memiliki sektor basis produksi rata-rata namun memiliki sektor luas tanam non basis. Tetapi pengaruh nilai pembagi dapat mempengaruhi hasil sektor basis/non basis kabupaten/kota pengaruh nilai pembagi yaitu, pt (nilai total produksi komoditas hortikultura tanaman sayur-sayuran pada tingkat kabupaten di Provinsi Sumatera Utara) sangat berpengaruh karena semakin rendah nilai total luas tanam komoditas hortikultura pada tingkat kabupaten/kota maka semakin besar nilai sektor basis kabupaten/kota sebaliknya jika semakin besar nilai total 
luas tanam komoditas hortikultura pada tingkat kabupaten/kota maka semakin rendah atau sektor non basis kabuapten/kota yang ada Provinsi Sumatera Utara. Karena itu pemerintah juga harus melihat kabupaten yang memiliki luas tanam non basis tetapi memiliki produksi yang besar berarti pemerintah daerah harus lebih cermat dalam menentukan kebijakan pembangunan perluasan tanaman dan dalam memeberi bantuan dengan melihat kabupaten yang memiliki potensi agar dapat dikembangkan untuk kedepannya agar tercapai target swasembada. Jika mengacu teori ekonomi basis sektor yang memiliki potensi besar dalam menentukan pembangunan menyeluruh di daerah merupakan kegiatan yang berorientasi ekspor barang dan jasa ke luar batas wilayah perekonomian yang bersangkutan karena sektor ini telah mencukupi kebutuhan di dalam wilayah itu sendiri dan satu-satunya sektor yang bisa meningkatkan perekonomian adalah sektor basis.

Dari kebijakan pembangunan pertanian tanaman cabai dilakukan untuk meningkatkan produksi cabai, Derektorat Jenderal Hortikultura Kementan Spudik Sujono mengatakan alokasi dana Rp 457 Miliar digunakan untuk program luas tambah tanam perkebunan aneka cabai sebanyak 15.000 hektar. Dia menegaskan, alokasi dana tersebut akan di berikan kepada sejumlah daerah sentra produksi cabai di seluruh Indonesia, dan anggaran untuk wilayah luar Jawa akan ditingkatkan (Tribun Medan, Rabu, 28 desember 2016 18:45)

Kebijakan Provinsi Sumatera Utara di tahun 2017 fokus pada pengembangan cabai hal tersebut disampaikan kepala Sub bagian Progam Dinas Pertanian Tanaman Pangan dan Hortikultura Sumatera Utara, Marino. Ia menjelaskann cabai difokuskan karena kerap pemicu infalasi harus di kembangkan dan di targetkan menjadi swasembada, Kementan melalui Dinas Pertanian Tanaman Pangan dan Hortikultra meminta tahun 2017 ini fokus menanam cabai. Selama ini cabai besar di fokuskan di daerah dataran tinggi saja, sedangkan sekarag daerah dataran rendah juga difokuskan untuk menanamnya. Daerah yang akan di tanamin di Sumatera utara yaitu, Batubara, Asahan, Simalungun, Langkat, Deli Serdang, Serdang berdagai, Tapanuli Selatan, Mandailing Natal. Berbagai langkah diamabil untuk tercapainya produksi swasembada cabai antara lain pemberian bibit ke kelompok petani dan bantuan pupuk maupun sarana pertanian lainnya (Tribun Medan, jumat 24 Februari 2017, 16:08)

Cabai menjadi salah satu fokus pengembangan dan masuk dalam program upaya khusus hal itu berdasarkan arahan Menteri Pertanian Republik Indonesia. Karena itu target luas tanam cabai di provinsi Sumatera Utara cukup tinggi yakni 37,101 ha. Target tersebut memang tinggi jika merujuk pada pencapaian di tahun 2016. Demikian dikatakan Plt Kepala Dinas Tanaman Pangan dan Hortikultura Sumut M. Azhar Harahap (Gosumut.com, Jum'at, 31 Maret 2017 11:33 WIB)

Dari hasil wawancara saya dengan ketua program Dinas Pertanian Tanaman Pangan dan Hortikultura Sumatera Utara H. Mugiono, SP beliau mengatakan untuk tahun 2018 fokus pada pengembangan luas tanam cabai. Ia menjelaskan cabai ini selalu inflasi untuk mengurangi inflasi Dinas Pertanian Tanaman Panagan dan Hortikultura Sumatera Utara memberi bantuan bantuan perluasan tanaman cabai di daerah yanag memiliki produksi cabai yang besar dan tidak terlalu besar. Daerah yang akan ditanamin di 
Sumatera Utara yaitu, kabupaten simalungun 20 ha, kabupaten Serdang Bedagai 5 ha, kabupaten Langkat 20 ha, kabupaten Tanah Karo 20 ha, kabupaten Mandailing Natal 20 ha, kabupaten Humb. Hasundutan 13 ha, kabupaten Tapanuli Utara 10 ha, kabupaten Tapanuli selatan 15 ha. Dinas Pertanian Tanaman Pangan dan Hortikultura Sumatera Utara juga memberi bantuan berupa pupuk, insektisida, fungisida, hebrisida dan mulsa. Tujuan perluasan lahan untuk meningkatkan luas panen dan produksi.

Dari kebijakan pembangunan pertanian tanaman cabai yang dilakukan Dinas Pertanian Tanaman Pangan dan Hortikultura Sumatera Utara tahun 2017 dan 2018 dalam mempeluas tanaman cabai untuk meningkatkan produksi setiap Kabupaten/Kota. Dari Kabupaten perluasan tanam cabai yang dilakukan Dinas Tanaman Pangan dan Hortikultura Sumatera Utara tahun 2017 dan 2018 jika dilihat dari hasil rata-rata LQ luas tanam cabai besar sektor basis dari tahun 2007-2016 yaitu, Kabupaten Batu Bara, Kabupaten Langkat, Kabupaten Tapanuli Selatan, Kabupaten Tapanuli Utara, Kabupaten Mandailing Natal dan Kabupaten Humbang Hasundutan memiliki sektor basis luas tanam dan produksi. Dengan adanya kebijakan perluasan tanam cabai yang dilakukan pemerintah daerah dapat meningkatkan produksi kabupaten untuk kedepannya, tidak terjadi inflasi, tercapainya target swasembada.

\section{SIMPULAN}

Berdasarkan hasil Analisis Location Quotient (LQ) mengenai tanaman cabai di Provinsi Sumatera Utara maka dapat diambil beberapa kesimpulan sebagai berikut: 1 . Kabupaten yang memiliki sektor basis luas tanam cabai besar di Provinsi Sumatera Utara dari tahun 2007-2016 dari 33 kabupaten/kota analisis Location Quotient (LQ) terdapat 11 kabupaten sektor basis luas tanam tanaman cabai besar yaitu, kabupaten Batu Bara, kabupaten Phak-phak Bharat, kabupaten Dairi, kabupaten Humbang Hasundutan, kabupaten Padang Lawas Utara, kabupaten Langkat, kabupaten Mandailing Natal, kabupaten Tapanuli Selatan, kabupaten Nias Utara, kabupaten Tanah Karo, kabupaten Tapanuli Utara. 2. Adapun kabupaten yang memiliki sektor basis produksi cabai besar di provinsi Sumatera Utara dari tahun 2007-2016 dari 33 kabupaten/kota analisis Location Quotient (LQ) terdapat 13 kabupaten sektor basis tanaman cabai besar yaitu, kabupaten Phak-phak Bharat, kabupaten Batu Bara, kabupaten Mandailing Natal, kabupaten Lanagkat, kabupaten Nias, kabupaten Tapanuli Selatan, kabupaten Tapanuli Utara, kabupaten Toba Samosir, kabupaten Humbang Hasundutan, kabupaten Padang Lawas Utara, kabupaten Deli Serdang, kabupaten Dairi, kabupaten Labuhan Batu.

\section{DAFTAR PUSTAKA}

Adetiya, N., Hutapea, S., \& Suswati, S. (2017). Pertumbuhan Dan Produksi Tanaman Cabai Merah (Capsicum annum L.) Bermikoriza Dengan Aplikasi Biochar Dan Pupuk Kimia. Agrotekma: Jurnal Agroteknologi dan Ilmu Pertanian, 1(2), 126-143. doi:https://doi.org/10.31289/agr.v1i2.1130

Agustina, R. (2014). Analisis Strategi Pengembangan Sektor Pertanian Di Kabupaten Magelang Pasca Erupsi Merapi. Publikasi Karya Ilmiah. Universitas Muhammadiya Surakarta

Dalimunthe, B.M., Azwan, A., \& L. Panggabean, E. (2017). Pertumbuhan Dan Produksi Tanaman Cabai (Capsicum annum L.) Terhadap Pemberian Pupuk Organik Pada Berbagai Media Tanam. Agrotekma: Jurnal Agroteknologi dan Ilmu Pertanian, 1(1), 1-11. doi:https://doi.org/10.31289/agr.v1i1.1097

Bafadal, A. (2014). Analisis Sektor Basis Pertanian Untuk Pengembangan Ekonomi Daerah. Universitas Hulu Oleo Kendari. Kendari. Volume. 24 No. 2 
BPS Provinsi Sumatera Utara. (2017). Provinsi Sumatera Utara dalam Angka 2017. Badan Pusat Statistik. Sumatera Utara

Eliyatiningsih, E., \& Mayasari, F. (2019). EFISIENSI PENGGUNAAN FAKTOR PRODUKSI PADA USAHATANI CABAI MERAH DI KECAMATAN WULUHAN KABUPATEN JEMBER. JURNAL AGRICA, 12(1), 7-16. doi:https://doi.org/10.31289/agrica.v12i1.2192

Harahap, M R. (2014). Analisis Sub Sektor Unggulan Yang Berdaya Saing Pada Sektor Pertanian Di kabupaten Langkat. Universitas Negeri Medan. Medan. Vol. 11 No. 2

Hendayana, R. (2003). Aplikasi Metode Location Quotient (LQ ) Dalam Penentuan Komoditas Unggulan Nasional. Jurnal Informatika Pertanian. Vol. 12.

Hidayah, I, (2010). Analisis Prioritas Komoditas Unggulan Perkebunan Daerah Kabupaten Buru (Preeminent Commodity Preference Analysis of Plantation of Sub-Province Buru). Jurnal AGRIKA, Volume 4, Nomor 1, Mei 2010.

http://m.gosumut.com/berita/baca/2017/03/31/2017-target-penanaman-cabai-di-sumut-cukup-ttinggi

http://medan.tribunnews.com/2016/12/28/genjot-produksi-cabai-dan-bawang-kementan-anggarkan-rp737-miliar

http://medan.tribunnews.com/2017/02/24/tekan-pemicu-inflasi-dinas-pertanian-fokus-pengembangancabai-dan-bawang-merah

Hutauruk, D. (2018). POTENSI BAKTERI KITINOLITIK NR09 PADA BEBERAPA MEDIA PEMBAWA DALAM MENGHAMBAT PERTUMBUHAN JAMUR PATOGEN Sclerotium rolfsii dan Fusarium oxysporum PADA BENIH CABAI MERAH (Capsicum annuum L.). BIOLINK : Jurnal Biologi Lingkungan Industri Kesehatan, 4(2), 138-151. doi:https://doi.org/10.31289/biolink.v4i2.1182

Ilyasa, M., Hutapea, S., \& Rahman, A. (2018). Respon Pertumbuhan dan Produksi Tanaman Cabai Rawit (Capsicum frutescens L) terhadap Pemberian Kompos dan Biochar dari Limbah Ampas Tebu. Agrotekma: Jurnal Agroteknologi dan Ilmu Pertanian, 3(1), 39-49. doi:https://doi.org/10.31289/agr.v3i1.1119

Iyan, R. (2014). Analisis Komoditas Unggulan Sektor Pertanian Di Wilayah Sumatera. Jurnal. Universitas Riau.

Laporan Kinerja Derektorat Jenderal Hortikultura tahun 2016

Larasati, N.D. (2017). Analisi Sektor Basis dan Sektor Unggulan Pembangunan Daerah dan Strategi Pengembangannya (Studi Kasus Di Kabupaten Malang). Naskah Publikasi Karya Ilmiah. Universitas Muhammadiyah Yogyakarta. Yogyakarata

Musrembangtan, (2017). Derektorat Jenderal Hortikultura tahun 2017.

Sihotang, S., Renfiyeni, R., Suliansyah, I., \& Jamsari, J. (2019). Induksi Kalus dengan BAP (Benzylaminopurin) dan IAA (Indoleacetic acid) pada Tanaman Cabai (Capsicum annuum L.) Lokal Genotipe Lotanbar Sumatera Barat. Agrotekma: Jurnal Agroteknologi dan Ilmu Pertanian, 3(2), 6774. doi:https://doi.org/10.31289/agr.v3i2.2547

Syahputra, E., Astuti K, R., \& Indrawaty, A. (2017). Kajian Agronomis Tanaman Cabai Merah (Capsicum annum L.) Pada Berbagai Jenis Bahan Kompos. Agrotekma: Jurnal Agroteknologi dan Ilmu Pertanian, 1(2), 92-101. doi:https://doi.org/10.31289/agr.v1i2.1127 